DOI: https://doi.org/10.34287/MMT.4(51).2021.1

N. Yu. Reznichenko ${ }^{1}$, Yu. G. Reznichenko ${ }^{2}$, G. I. Reznichenko ${ }^{1}$, K. O. Veretelnyk ${ }^{2}$

${ }^{1}$ State Institution «Zaporizhzhia Medical Academy of post-graduate education Ministry of Health of Ukraine» Zaporizhzhia, Ukraine

${ }^{2}$ Zaporizhzhia State Medical University

Zaporizhzhia, Ukraine

Н. Ю. Резніченко ${ }^{1}$ Ю. Г. Резніченко ${ }^{2}$ Г. І. Резніченко ${ }^{1}$, К. О. Веретельник ${ }^{2}$

${ }_{1}^{1}$ Державний заклад «Запорізька медична акаделія післядиплолної освіти Міністерства охорони здоров’я України» Запоріжжя, Украӥна

Запорізький державний медичний університет

Запоріжж, Україна

\title{
EFFICACY AND SAFETY OF 20\% AZELAIC ACID CREAM FOR PAPULO-PUSTULAR ACNE VULGARIS
}

\author{
Ефективність та безпека застосування 20\% крему \\ азелаїнової кислоти Аля мікування \\ папуло-пустульозної форми вульгарних акне
}

Abstract

Purpose of the study. To determine the safety and efficacy of $20 \%$ azelaic acid cream in the treatment of patients with papulopustular acne vulgaris.

Materials and methods. 65 patients with acne vulgaris were examined. The control group consisted of 30 healthy individuals. Acne severity was evaluated according to G. Michaelsson et al. scale, Cook's scale, absolute number of papules and pustules. Assessment of quality of life was performed. Facial skin microbiocenosis was assessed. All patients with acne vulgaris applied $20 \%$ azelaic acid cream during $15 \pm 2$ days.

Results and discussion. The use of $20 \%$ azelaic acid cream contributed to the rapid regression of inflammatory acne. After 10 days of treatment, the number of papulopustular elements decreased in 3 times. After 10 days of therapy acne score according to G. Michaelsson et al. decreased in 1,5 times and after 15 days of treatment - in 1,9 times. After 10 days of therapy the acne score on the Cook's scale decreased in 1,4 times. At the end of the study the acne score on the Cook's scale was 2,4 points. There was a significant decrease in the total number of bacteria, the number of coagulase-positive staphylococci, quantity of Propionibacterium acnes on facial skin in 15 days after the start of therapy. A significant difference in the average value of the $D L Q I$ was fixed before $(18,9 \pm 0,31)$ and at the end $(8,1 \pm 0,54)$ of treatment.
Peфepam

Мета дослідження. Визначити безпеку та ефрективність 20\% крелу азелаӥнової кислоти у лікуванні хворих на папуло-пустульозні акне.

Матеріали та методи. Обстежено 65 пацієнтів з вульгарнили акне. Контрольну групу склали 30 здорових осіб. Тяжкість акне оцінювали за G. Michaelsson et al., шкалою Кука, абсолютною кількістю папул $і$ пустул. Проведено оцінку якості життя. Оиінено лікробіоценоз шкіри обличчя. Усі пацієнти з вульгарнили акне протягол $15 \pm 2$ днів застосовували $20 \%$ крел азелаӥнової кислоти.

Результати та обговорення. Використання $20 \%$ крелу азелаїнової кислоти сприяло швидко му регресу запальних акне. Через 10 днів ліку вання кількість папуло-пустульозних елелентів зленшилась у 3 рази. Після 10 днів терапї оиінка акне за G. Michaelsson et al. знизилась у 1,5 рази та через 15 днів лікування - у 1,9 рази. Після 10 днів терапї показник акне за шкалою Кука знизився у 1,4 рази. Наприкіниі дослідження оцінка акне за шкалою Кука становила 2,4 бала. Через 15 днів після початку терапї спостерігалося достовірне зниження загальноі кількості бактерій, коагулазопозитивних ста філококів, кількості Propionibacterium acnes на шкірі обличчя. Достовірна різниия в середньому значенні DLQI була зафіксована до (18,9 $\pm 0,31)$ і в кінці $(8,1 \pm 0,54)$ лікування. 
Conclusions. The high effectiveness of $20 \%$ azelaic acid cream in treatment of papulopustular acne vulgaris was proved. $20 \%$ azelaic acid cream provides a rapid regression of inflammatory forms of acne, reduction of total quantity of bacteria and Propionbacterium acnes on skin. acid.

Keywords: acne vulgaris, treatment, azelaic

\section{INTRODUCTION}

One of the most actual problems in modern dermatology is acne vulgaris, which is a disease of the sebaceous glands and hair follicles, the functioning of which is associated with the influence of many factors. The importance of the problem of acne is primarily due to the prevalence of the disease. According to the literature data, acne vulgaris occupy the third place in the structure of dermatological diseases [1,2]. In the cohort of adolescents and young adults, the frequency of acne is much higher than the average, reaching $80-90 \%$ [3].

In $11 \%$ of people over the age of 25 there are acne rashes, which may be due to physiological changes in hormones according to the phases of the menstrual cycle in women or be a manifestation of hyperandrogenism [4].

Clinical manifestations of acne vulgaris most often appear at the age of 12-14 years, and the peak incidence in girls occurs at the age of 14-17 years and $16-19$ years - in boys $[1,4]$. This is followed by a regression of the rash, but the involution of acne occurs slowly in almost $20 \%$ of adolescents. Onset of acne can contribute to neurotic disorders and cause severe disease with the emergence of excoriated acne.

Acne vulgaris is a disease of the whole body associated with a multifaceted complex of interdependent histochemical and organ dysfunctions. Pathological changes in acne occur not only in the skin but also in various organs and systems of the human body. Fundamental research has revealed the mechanisms of acne, the pathogenesis and morphogenesis of rashes $[1,2]$. The leading role in the development of normal acne is played by four main interrelated mechanisms:

1) androgen-induced hyperproduction of sebum (which is associated with increased levels of androgens; increased activity of the enzymes 5 - $\alpha$-reductase, 3 - $\beta$-hydroxysteroid dehydrogenase and 17- $\beta$-hydroxysteroid dehydrogenase);

2) increased proliferation of follicular keratinocytes with disorders of their differentiation and desquamation, which leads to follicular hyperkeratosis and comedones;

3) colonization of sebaceous hair follicles by Propionbacterium acnes;

4) the development of inflammation.
Висновки. Доведено високу ефективність $20 \%$ крему азелаӥнової кислоти при лікуванні папуло-пустульозних акне. Крел $20 \%$ азелаїнової кислоти забезпечує швидкий регрес запальних форл акне, зленшення загальної кількості бактерій і Propionibacterium acnes на шкірі.

Ключові слова: акне вульгарні, лікування, азелаӥнова кислота.

In addition, in recent years, importance is attached to genetic factors and hereditary predisposition to the development of acne. After all, hereditary factors determine the structure and size of the sebaceous glands, the composition of skin secretions, keratinization activity. Hyperandrogenism and hypersensitivity of sebocytes to testosterone derivatives are genetically determined [5]. For example, PAPA-, PASH-, PASS-, SAPHO-syndromes are distinguished into separate syndromes. The autosomal dominant type of heredity of PAPA syndrome has been proved.

Along with opinions on the genetic causes of acne, much attention is paid to exogenous and endogenous factors [6]. When considering the exogenous causes of acne, a number of authors highlight alimentary factors, such as excessive consumption of carbohydrates and fats, others pay attention to the use of gonadotropic, estrogenic, corticosteroid hormones, iodine, bromine, lithium, quinine [6].

Some researchers focus on the effects of insolation, mechanical irritation of skin, constant skin contact with comedogenic agents (mineral oils, tar, lanolin and vaseline-based cosmetics - greasy creams, blushes, etc.).

One of the main reasons for the development of acne is the effect of androgens on the secretory activity of the sebaceous glands. A significant place in the etiology and pathogenesis of acne vulgaris is occupied by chronic endocrine pathology - menstrual disorders due to polycystic ovary syndrome, accompanied by anovulation and hirsutism; androgen-producing tumors; adrenal cortex dysfunction; imbalance of testosterone fractions in men.

It is generally accepted that the skin is the main link in the metabolism of sex steroid hormones, and the main target organs for them are hair follicles and sebaceous glands. A number of sex and gonadotropic hormones (ACTH, adrenal cortex hormones, testosterone, progesterone) stimulate the functional activity of the sebaceous hair follicle, and such as estrogen - suppress their activity.

During puberty the relationship between androgens and estrogens is disrupted, which causes acne in almost all people of this age. At the same time, there is an increase in the biosynthesis of skin enzymes such as 5-reductase, which converts free testosterone to dehydrotestosterone, which is 
involved in the hypersecretion of sebaceous glands. The causes of hyperandrogenism in women can be genetic, hypothalamic-pituitary, ovarian, adrenal disorders.

Changes in the qualitative and quantitative composition of sebum play an important role in comedones. It is known that sebum lipids consist of two components: epidermal lipids and lipids synthesized in the sebaceous gland. Hypersecretion of sebum, increase in synthesis of lipids in sebaceous glands, decrease in formation of lipids in keratinosomes of epidermis is noted in cases of acne vulgaris. Therefore, one of the links in the pathogenesis of acne is an excess of polyunsaturated fatty acids due to impaired metabolism of free fatty acids. Secretion of sebum depends on many factors: age, sex, body temperature, biorhythms and is the main indicator of androgenic activity.

Increased production of sebum with a decrease in unsaturated fatty acids promotes the reproduction of Propionbacterium acnes. Bacterial lipases of Propionbacterium acnes promote the formation of free fatty acids, which leads to the development of comedones and aseptic inflammation. Thus, the development of inflammatory forms of acne is associated with the reproduction of opportunistic pathogens in the sebaceous glands. Inflammatory processes of varying intensity can develop in the skin at any stage of acne $[7,8]$.

Numerous studies have shown that the species and quantitative composition of microorganisms in human skin is stable, despite the action of various factors. The skin has a certain protective barrier due not only to the integrity of the integument, but also due to the composition of sebum, which controls the microbiocenosis due to fatty acids. The secretion of sebaceous glands is a favorable environment for the reproduction of $\mathrm{P}$. acnes, and reducing the level of unsaturated fatty acids weakens the bactericidal properties of sebum [9, 10].

Considering theliteratureon themicrobiocenosis of the skin, the species of the dominant microflora in acne, there are some contradictions in the views of various authors on this issue. Some studies have shown that in addition to P. acnes, staphylococci and streptococci are secreted on the skin both outside the elements of the rash and directly in the acne elements [11]. It should be noted that most researchers believe that the pathogenetically significant causative agent of inflammatory forms of acne is Propionbacterium acnes, which are most often isolated from the excretory ducts of the sebaceous glands.

Guidelines of care for the management of acne vulgaris, published in the Journal of the American Academy of Dermatology in 2016, provide data on the low importance of routine use of microbiological studies toassess thecausativeagent of inflammatory forms of acne. First of all, this is justified by the fact that $\mathrm{P}$. acnes is a completely proven etiological factor in the occurrence of papulopustular rashes in acne vulgaris [6]. Secondly, the lack of need to determine the types of bacteria in the acne elements is due to the fact that their definition does not affect the success of antibacterial therapy for acne.

Tetracycline antibiotics have been identified as systemic first-line antibacterial drugs because they have an additional anti-inflammatory effect. At the same time, the most effective topical antiseptic agent for the treatment of inflammatory forms of acne is azelaic acid.

P. acnes synthesizes various chemoattractants that attract leukocytes and enzymes to the site of inflammation, which leads to damage to the wall of the sebaceous gland and hair follicle. The development of the inflammatory process depends on the state of the protective properties of the skin and the action of bacterial metabolites. Thus, P. acnes is characterized by: induction of proinflammatory cytokines; synthesis of antigens that stimulate the synthesis of antibodies; in addition, they produce vasoactive amines, such as histamine, which enhances inflammation.

$P$. acnes is characterized by resistance to neutrophil and monocyte damage, persistence in phagocytic cells, where microorganisms remain viable for a long time, despite antibiotic therapy. In addition, the overproduction of sebum does not allow to create the required concentration of antibiotic in the ducts of the sebaceous glands. These features of propionic acid bacteria allow them to exist for a long time in the sebaceous hair follicles, despite the treatment of acne. This is why topical antibacterials are considered the most effective in eliminating inflammatory forms of acne.

Azelaic acid used to treat acne have multiple effect - antiseptic, comedolytic, mild keratolytic and depigmenting effects. Topical antibiotics are less effective than azelaic acid due to resistance of staphylococci and P. acnes.

As acne vulgaris is an extremely relevant dermatological problem, we decided to conduct our own research to determine the optimal methods of treatment with topical action.

Therefore, the objective of our study was to determine the safety and efficacy of $20 \%$ azelaic acid cream in the treatment of patients with papulopustular acne vulgaris.

\section{MATERIALS AND METHODS}

65 patients with acne vulgaris aged 18 to 30 years were examined, of which: 38 women and 27 men. The study included individuals with papulopustular form of the disease. Extremely severe forms of acne, such as acne conglobata, inverse acne, fulminant acne (which required potent systemic therapy) were the exclusion criteria. The control group consisted of 30 healthy individuals without signs of 
dermatological diseases (including acne vulgaris) aged 18 to 30 years: 15 women and 15 men. All subjects signed informed consent form before any procedures of the study.

In order to objectively assess the severity of acne vulgaris a score according to G. Michaelsson et al. in the modification of V. P. Sergeev, V. N. Rokitskaya and the scale of evaluation of acne elements according to Cook were used during the study. The method of calculating the index of acne according to G. Michaelsson et al. in modification of V. P. Sergeev, V.N. Rokitskaya was carried out as follows: number of various elements of an acne rash were multiplied by the corresponding point and summed up (Table 1). Points that reflected the degree of background erythema were added to the obtained amount. The total score formed the index of acne.

Scoring of elements of acne by G. Michaelsson et al. in modification

Table 1 by V. P. Sergeev, V. N. Rokitskaya

\begin{tabular}{|l|c|}
\hline \multicolumn{1}{|c|}{ Elements of acne } & Score in points \\
\hline Comedone & 0,5 \\
\hline Papule & 2,0 \\
\hline Pustule & 3,0 \\
\hline Infiltrate & 4,0 \\
\hline Cyst & 4,0 \\
\hline Tubercule & 5,0 \\
\hline Abscess & 5,0 \\
\hline Erythema around the elements: & \\
limited (first degree) & 25,0 \\
common (II degree) & 50,0 \\
total with the presence of edema (III degree) & 75,0 \\
\hline
\end{tabular}

Scoring of acne elements on the Cook's scale was performed on the following skin characteristics:

0 points - small number of small comedones or papules on the skin, which are visible only when viewed at close range;

2 points - about $1 / 4$ of the face is affected by 6-12 small papules or comedones (a small number of large comedones or 20-30 small closed comedones may be present);

4 points - about $1 / 2$ of the surface of the face is affected by small papules and comedones of different sizes, pustules (6-12) or large comedones that protrude above the skin surface may be present (if there are larger lesions, the skin condition can be qualified by gradation in 4 points, even if less than half of the face is affected);

6 points - papules and/or large open comedones are present on approximately $3 / 4$ of the face surface (smaller area of facial lesion is possible if inflammatory elements are larger in size), usually more than 18 pustules are present;

8 points - almost the entire surface of the face is affected, there are large pustules, there may be acne conglobata, cystic elements.

In addition, to assess the severity of acne and the effectiveness of their treatment, the absolute number of papules and pustules was taken into account.

Clinical examination of the skin in patients with acne vulgaris was performed before treatment, on Day $10 \pm 1$, Day $15 \pm 2$ days, after treatment.
Assessment of quality of life was performed according to DLQI (Dermatology Life Quality Index). It consists of 10 questions, the answers to which should reflect how the skin disease has affected the patient's life during the last week. An authorized Ukrainian translation of the DLQI questionnaire (Ukrainian version of DLQI) was used.

All patients underwent general clinical examinations and, if necessary, consultations with a gynecologist, endocrinologist, and gastroenterologist.

Facial skin microbiocenosis was assessed by direct qualitative and quantitative method in all patients before treatment and on Day $15 \pm 2$ days after its onset. Microbial contamination on the affected areas of skin was expressed in Lg CFU (colony-forming units) per $1 \mathrm{ml}$ of pathological material, on unaffected skin - in Lg CFU per $1 \mathrm{~cm} 2$.

All patients with acne vulgaris who were included in the study applied $20 \%$ azelaic acid cream on cleansed skin of the affected areas (on the face, if necessary - on the neck, back, shoulders) 2 times a day (in the morning and in the evening). The duration of treatment was $15 \pm 2$ days.

In order to compare the indicators in different groups, the double criterion of the Student with the calculation of the arithmetic mean (M) and the standard error of the arithmetic mean $(\mathrm{m})$ or the Wilcoxon sign criterion, depending on the normality of distribution, was applied. Normality 
of data distribution was verified using the Shapiro-Wilk criterion at the significance level of 0,01. In applying all statistical methods, besides the criterion of Shapiro-Wilk, the significance level was taken to be 0,05 - the difference between the data was considered reliable at $\mathrm{P}<0,05$.

\section{RESULTS AND DISCUSSION}

According to the collected anamnesis, it was found that the duration of acne vulgaris before inclusion in the clinical study ranged from 3 months to 8 years.

A number of concomitant diseases were found in some of the examined patients, the most common of which were: hyperandrogenic conditions (verified by an obstetrician-gynecologist in $68,4 \%$ of examined female patients), pathology of the gastrointestinal tract and hepatobiliary system (chronic gastritis, duodenitis, duodenitis). stomach and duodenum, dyskinesia of the biliary tract) - in $33,8 \%$ of patients with acne.

The questionnaire found that the average DLQI index before treatment in patients with acne was 18,9 points, which indicates a pronounced impact of acne on the quality of life of patients. The high values of the DLQI index in patients are explained by the lesion of exposed areas of the skin and the difficulty in masking aesthetic changes in the facial area.

Counting the number of elements of the rash and the overall assessment of the skin allowed us to determine that the average score of acne elements on the Cook's scale at the beginning of the study was 6,01 points, and the index of acne according to G. Michaelsson et al. in the modification of V. P. Sergeev, V. N. Rokitskaya - 319,1 points.

The results of microbiological examination of the skin conducted in patients with acne vulgaris before treatment are provided in table 2. As can be seen from the table, patients with acne have changes in microbial contamination of the skin not only in the affected but also in intact areas of the skin. Thus, in patients with acne vulgaris there was a statistically significant increase in the total number of bacteria, as well as coagulase-positive staphylococci on unaffected areas of skin, compared with the control group of healthy individuals.

We analyzed the results of the study obtained after 15 days of treatment of patients with acne vulgaris. First of all, it should be noted the normal tolerability of $20 \%$ azelaic acid cream, the absence of toxic and allergic reactions during its use. After treatment, there was no deterioration in the results of general clinical tests, biochemical blood tests and creatinine clearance. Therefore, the obtained data prove the safety of using $20 \%$ azelaic acid cream in dermatological practice.

The use of $20 \%$ azelaic acid cream contributed to the rapid regression of inflammatory acne elements - papules and pustules (figure 1). Thus, after 10 days of treatment, the number of papulopustular elements in patients decreased by 3 times. After 15 days of therapy, inflammatory acne elements in patients were isolated or completely absent.

The established changes in the number of individual elements of the rash during treatment were reflected in the unified scores of the severity of acne vulgaris. As can be seen from, there was a decrease in the index of acne in patients with acne vulgaris during treatment according to G. Michaelsson et al. in modification by V. P. Sergeev, V. N. Rokitskaya (figure 2). After 10 days of therapy with $20 \%$ azelaic acid cream index of acne decreased by 1,5 times. And after 15 days of treatment in patients who used $20 \%$ azelaic acid cream, the index of acne was 1,9 times lower than in patients before therapy.

Similar trends were observed in the Cook's scale of acne elements. As can be seen from, there was a decrease in this score during treatment in patients with acne vulgaris (figure 3). After 10 days of therapy with the use of $20 \%$ azelaic acid cream, the score of acne elements on the Cook's scale decreased by 1,4 times. At the end of the study the acne score on the Cook's scale was only 2,4 points in group of subjects who used $20 \%$ azelaic acid cream.

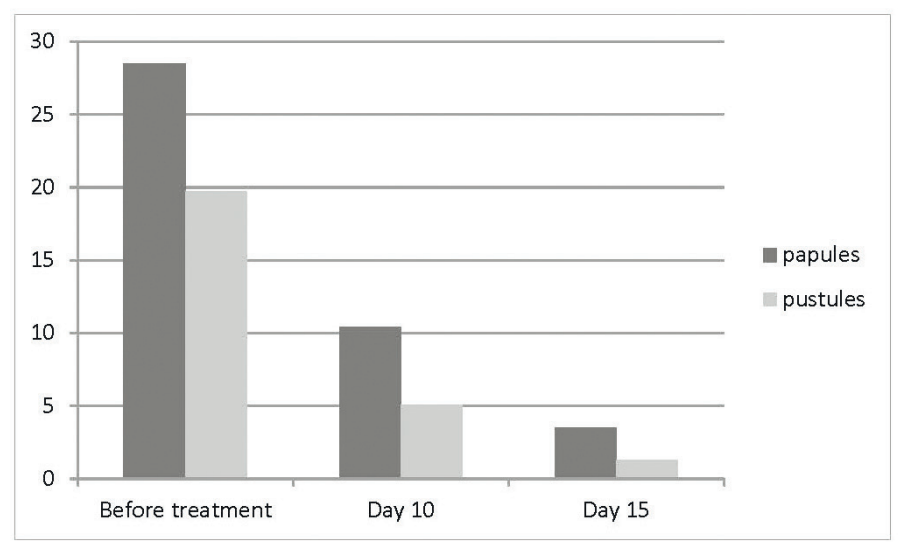

Figure 1. The number of papules and pustules in the treatment of patients with acne vulgaris 


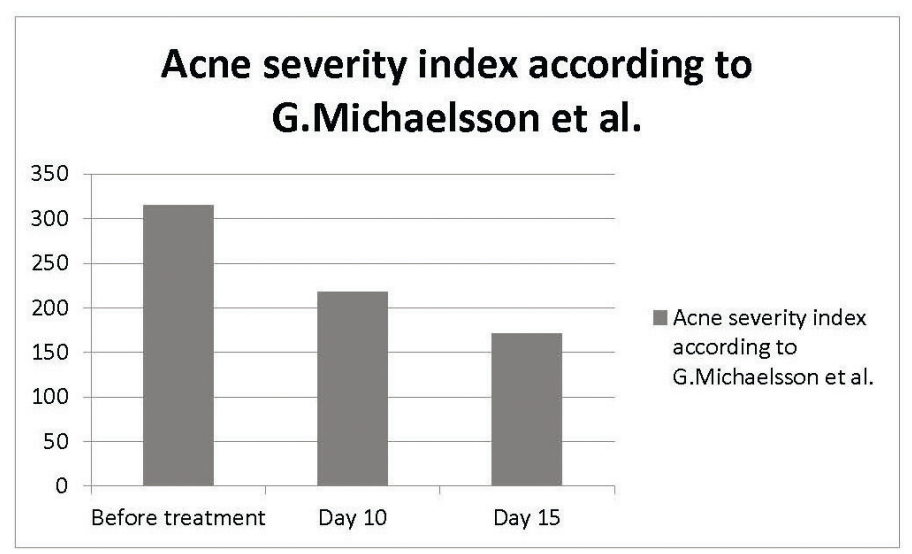

Figure 2. Acne severity index according to G. Michaelsson et al. in modification of V. P. Sergeev, V. N. Rokitskaya changes during treatment course

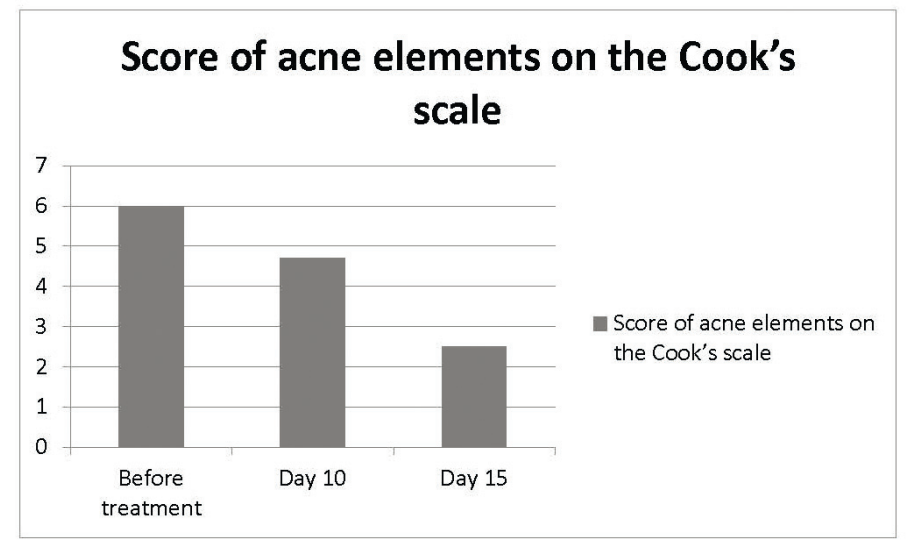

Figure 3. Score of acne elements on the Cook's scale during treatment course

Thus, the data obtained during the study indicate a pronounced clinical efficacy of the $20 \%$ azelaic acid cream for the treatment of patients with papulopustular acne. We also evaluated the effect of $20 \%$ azelaic acid cream on the skin microbiocenosis. The results of the study are presented in table 2 . As can be seen from the table, there was a statistically significant decrease in the total number of bacteria and the number of coagulase-positive staphylococci on unaffected areas of skin in 15 days after the start of therapy in patients.
In addition, there were changes in microbial contamination of the affected areas of the skin. There was a significant decrease in both - the total number of bacteria and the number of coagulasepositive staphylococci in the lesions after 15 days of application of $20 \%$ azelaic acid cream. At the same time, patients had a significantly lower quantity of Propionibacterium acnes in $\mathbf{1 5}$ days after the start of treatment, compared with their number before the start of therapy, which indicates a pronounced antiseptic effect of $20 \%$ azelaic acid cream.

Table 2

Skin microbiocenosis in the treatment of patients with acne vulgaris

\begin{tabular}{|l|c|c|c|c|}
\hline \multicolumn{2}{|c|}{ Indexes } & $\begin{array}{c}\text { Control group } \\
\text { of healthy } \\
\text { individuals }\end{array}$ & $\begin{array}{c}\text { Patients } \\
\text { before } \\
\text { treatment }\end{array}$ & $\begin{array}{c}\text { Patients in 15 } \mathbf{2} \text { days } \\
\text { from the beginning } \\
\text { of treatment }\end{array}$ \\
\hline \multirow{3}{*}{$\begin{array}{l}\text { Unaffected area } \\
\text { of skin (Lg CFU/cm }\end{array}$} & Total number of bacteria & $2,91 \pm 0,12$ & $4,98 \pm 0,24^{*}$ & $3,27 \pm 0,29 \bullet$ \\
\cline { 2 - 5 } & Staphylococci, coagulase-negative & $1,15 \pm 0,19$ & $1,68 \pm 0,31^{*}$ & $1,5 \pm 0,48$ \\
\cline { 2 - 5 } & Staphylococci, coagulase positive & $0,24 \pm 0,09$ & $1,89 \pm 0,34^{*}$ & $0,25 \pm 0,26 \bullet$ \\
\hline \multirow{3}{*}{$\begin{array}{l}\text { Affected skin } \\
(\text { Lg CFU/cm })\end{array}$} & Total number of bacteria & & $6,62 \pm 0,59$ & $4,58 \pm 0,48 \bullet$ \\
\cline { 2 - 5 } & Propionibacterium acnes & & $2,72 \pm 0,36$ & $0,49 \pm 0,19 \bullet$ \\
\cline { 2 - 5 } & Staphylococci, coagulase-negative & & $1,80 \pm 0,27$ & $1,55 \pm 0,42$ \\
\cline { 2 - 5 } & Staphylococci, coagulase positive & & $3,24 \pm 0,45$ & $1,16 \pm 0,39 \bullet$ \\
\hline
\end{tabular}

Notes: * significant difference $(P<0,05)$ in comparison with the group of healthy people;

- - significant difference $(P<0,05)$ between the relevant indicators before and after treatment 
Along with the improvement of the clinical picture of the disease, the quality of life of patients also improved. We obtained a statistically significant difference in the average value of the DLQI index before $(18,9 \pm 0,31)$ and at the end $(8,1 \pm 0,54)$ of the treatment course with $20 \%$ azelaic acid cream for acne vulgaris. An important indicator of the effectiveness of the therapeutic course is also DLQI $<5$ (the number of subjects in whom the DLQI index was less than 5 points after treatment course. Such DLQI level was observed in $60,0 \%$ of patients who used $20 \%$ azelaic acid cream for 15 days. This suggests that the use of $20 \%$ azelaic acid cream in the treatment of acne vulgaris leads to a significant reduction in the impact of the disease on the quality of life of patients. These data indicate the effectiveness of $20 \%$ azelaic acid cream in the treatment of papulopustular acne.

\section{CONCLUSIONS}

A review of the literature data and the results of our own research prove the high effectiveness of $20 \%$ azelaic acid cream in the treatment of papulopustular acne vulgaris. Topical use of $20 \%$ azelaic acid cream provides a rapid regression of inflammatory forms of acne, reducing the total number of bacteria and the quantity of Propionbacterium acnes on the skin, as well as improves the quality of life of patients. These facts permit to recommend the widespread use of $20 \%$ azelaic acid cream in dermatological practice in the treatment of papulopustular forms of acne vulgaris.

Authors disclaims any conflict of interests and the existence of finance.

\section{REFERENCE}

1. Dawson AL, Dellavalle RP. Acne vulgaris. BMJ. 2013 May 8. 346: 2634. doi: 10.1016/S01406736(11)60321-8.

2. Kelhälä HL, Fyhrquist N, Palatsi R, et al. Isotretinoin treatment reduces acne lesions but not directly lesional acne inflammation. Exp Dermatol. 2016 Jun. 25 (6): 477-8. doi: 10.1111/ exd.12971.

3. Saluja SS, Walker ML, Summers EM, Tristani-Firouzi P, Smart DR. Safety of non-ablative fractional laser for acne scars within 1 month after treatment with oral isotretinoin: A randomized split-face controlled trial. Lasers Surg Med. 2017 Dec. 49 (10): 886-890. doi: 10.1002/lsm.22711.

4. Baek JH, Ahn SM, Choi KM, Jung MK, Shin MK, Koh JS. Analysis of comedone, sebum and porphyrin on the face and body for comedogenicity assay. Skin Res Technol. 2016 May. 22 (2): 164-9. DOI: $10.1111 /$ srt.12244.

5. Schmidt TH, Khanijow K, Cedars MI, Huddleston H, Pasch L, Wang ET, et al. Cutaneous Findings and Systemic Associations in Women With Polycystic Ovary Syndrome. JAMA Dermatol. 2016 Apr. 152 (4): 391-8. doi: 10.1001/ jamadermatol.2015.4498.

6. Zaenglein AL, Pathy AL, Schlosser BJ, Alikhan A, Baldwin HE, Berson DS, et al. Guidelines of care for the management of acne vulgaris. J Am Acad Dermatol. 2016 May. 74 (5): 945-973.e33. doi: 10.1016/j.jaad.2015.12.037.

7. Eichenfield LF, Lain T, Frankel EH, Jones TM, Chang-Lin JE, Berk DR, et al. Efficacy and Safety of Once-Daily Dapsone Gel, $7,5 \%$ for Treatment of Adolescents and Adults With Acne Vulgaris: Second of Two Identically Designed, Large, Multicenter, Randomized, Vehicle-Controlled Trials. J Drugs Dermatol. 2016 Aug 1. 15 (8): 962-9. https://pubmed.ncbi.nlm.nih.gov/27537997/.

8. Raoof TJ, Hooper D, Moore A, Zaiac M, Sullivan T, Kircik L, et al. Efficacy and Safety of a Novel Topical Minocycline Foam for the Treatment of Moderate-to-Severe Acne Vulgaris: A Phase 3 Study. J Am Acad Dermatol. 2019 Jun 1. doi: 10.1016/j.jaad.2019.05.078.

9. Gold LS, Dhawan S, Weiss J, Draelos ZD, Ellman H, Stuart IA. A novel topical minocycline foam for the treatment of moderate-to-severe acne vulgaris: Results of 2 randomized, double-blind, phase 3 studies. J Am Acad Dermatol. 2019 Jan. 80 (1): 168-177. doi: 10.1016/j.jaad.2018.08.020.

10. Hebert A, Thiboutot D, Stein Gold L, Cartwright M, Gerloni M, Fragasso E, et al. Efficacy and Safety of Topical Clascoterone Cream, $1 \%$, for Treatment in Patients With Facial Acne: Two Phase 3 Randomized Clinical Trials. JAMA Dermatol. 2020 Apr 22. DOI: 10.1001/ jamadermatol.2020.0465.

11. Moore A, Green LJ, Bruce S, Sadick N, Tschen E, Werschler P, et al. Once-Daily Oral Sarecycline $1.5 \mathrm{mg} / \mathrm{kg} /$ day Is Effective for Moderate to Severe Acne Vulgaris: Results from Two Identically Designed, Phase 3, Randomized, Double-Blind Clinical Trials. J Drugs Dermatol. 2018 Sep 1. 17 (9): 987-996. https://pubmed.ncbi. nlm.nih.gov/30235387/. 